Avaing Tera
LingTera, 6 (1), 2019, 1-7

\title{
The comparative study between Indonesian and English blend words
}

\author{
Mia Rahmannia *, Pratomo Widodo \\ Department Applied Linguistics, Graduate School, Universitas Negeri Yogyakarta \\ Jalan Colmbo No. 1, Karangmalang, Yogyakarta 55281, Indonesia \\ * Coresponding Author. E-mail: mia.rahmannia.enginsea@gmail.com \\ Received: 1 January 2019; Revision: 4 April 2019; Accepted: 4 April 2019
}

\begin{abstract}
Generally, the definition of blending is combining two clipped words. Kvetko in Bednarova defines blending as a word formation process similar to shortening combined with merging two different words. There are many types of blending words both in Indonesian and English context. Therefore, the aim of this research is to analyze the comparison between Indonesian blend words and English blend words in terms of its types, its similarities and differences and also how its formed. In this paper the researcher use descriptive qualitative method as the method of the research. The researcher used some journal articles relevant to blend words both in Indonesian and English context to be the source of the data. The result showed that Indonesian blend words and English blend words not only have similarities in the forming word, but also have their differences that make them unique to each other. The researcher hopes that the reader of this article gets more information about both Indonesian and English blend words based on its types and the similarities and the difference between them.
\end{abstract}

Keywords: comparative study, Indonesian blend words, English blend words, types of blending

How to Cite: Rahmannia, M., \& Widodo, P. (2019). The comparative study between Indonesian blend words and English blend words. LingTera, 6(1), 1-7. doi:https://doi.org/10.21831/lt.v6i1.22785

This is an open access article under the CC-BY-SA license.

\section{INTRODUCTION}

In daily life, people need a way to communicate each other (Hamelink, 2004). Such way is a language. Every country has its own mother tongue to interact each other (Rizkiyanto, 2014). The language can be improved in accordance with the development of globalization era. Along with the development of the age, information and technology have affected the numbers of vocabulary of a language. But not all the words can be improved especially in increasing the number of nouns. The writer took this topic in the research is because the writer is interested in finding out the comparison (both similarities and differences) between Indonesian blend words and English blend words. Generally, blending can be defined as combining two clipped words. Kvetko in Bednárová-Gibová (2014) defines blending as a word formation process similar to shortening combined with merging two different words. In addition, Blending is the results of two clipped words that are blended together (Giyatmi, Wijayava, \& Arumi, 2017; Peresich, 2015).
Furthermore, a blend may be defined as a new lexeme formed from parts of two (or possibly more) other words in such a way that there is no transparent analysis into morph (Bauer, \& Laurie, $1983,234)$. Blends is a new word that is derived from two source words or splinters that at least one of them is shortened before being blended such as in English digital + camera (digicam), social + media (sosmed), information + entertainment (infotainment).

The writer took this topic in the research is because the writer is interested in finding out the comparative study (the similarities and differences) between Indonesian blend words and English blend words. In Indonesian context, there is a term called an acronym. According to Zimmer (2010), acronym is more expansive, encompassing any abbreviation formed from initial letters regardless of pronunciation. Therefore, an acronym can call an abbreviation. For example; Pilkada (Pemilihan Kepala Daerah), Balita (Bawah Lima Tahun). From the statement, we can see that the principle of blend word in 
Bahasa Indonesia mixes up with Indonesian acronym (Permatasari, \& Suyudi, 2011). Meanwhile in English context, the previous research shows that most of the blends are made by clipping and overlapping. According to the previous research by Giyatmi et al (2017), there are some different patterns that can be used to form blending with clipping, one of them is by keeping the first part of the first splinter and the last parts of the second splinter such as brunch (breakfast + lunch), smog (smoke+ fog). While, the overlapping can happen in one or several phonemes such as slanguage (slang+language), sexpert (sex+expert), playbore (playboy+bore), cartune (cartoon + tune), sinema (sin+cinema), cellebrity (cell + celebrity).

So far the previous researches have already examine types of blending both in English and in Indonesian context and how the blends are formed. But there have been no research that discuss about the comparison between the two of them including the similarities and the differences between both of them. Thus, the researcher is curious to find out about the comparative study between Indonesian blend words and English blend words. Its comparison will be analyze based on its types and how blend words are formed both in English and Indonesian context.

\section{METHOD}

This research concerns to the comparative study between Indonesian blend words and English blend words. In this research the writer use descriptive qualitative method as the method of the research. A qualitative study is defined as an inquiry process of understanding a social or human problem, based on building a complex, holistic picture, formed with words, reporting detailed views of informants, and conducted in a natural setting (Cresswell, 1994). The sources of data are collected from some articles journal which discuss related topic about blending words both in Indonesian and English context. There will be no participant in this research because the source of data is taken from some journal articles and books that related with Indonesian and English blend words. The data that were gather are analyzed and processed using content analysis technique. Barelson (1954) states that content analysis is objective, systematic, and descriptive qualitative research technique to manifest communication (Graneheim, \& Lundman, 2004). It means that analyzing data provide depth and detail through direct quotation and careful description of program situation, events, interactions and observed behaviour. The data used in this research shaped in language forms. The data is not about numbers, that's why this research does not use statistics and rejection hypothesis. The steps to analyze the data are; (a) Read and comprehended some articles journal about Indonesian and English blend words; (b). Collecting the data related to the aim of study; (c). Analyzing the data collected with placed on appropriate forms of each the blend language types; (d) Making a conclusion based on the data.

\section{RESULT AND DISCUSSION}

\section{Result}

From the result of the discussion the writer make two tables (Table 1 and Table 2) which contains the similarities and the differences between Indonesian blend words and English blend words. From the Table 1, the writer finds that similarities of Indonesian blend words and English blends words are in the types of blend in Table 1; (1) Blends created by using the first bit of the first word, the last bit of the second one; (2) Blends created by using the first parts of the words; (3) and blends created by using the last parts of the words. Apart from the three types of blending words that mentioned before, other types of blending words are different or not the same, as you can see in Table 2.

Table 1. The Similarities of Indonesian Blend Words and English Blend Words

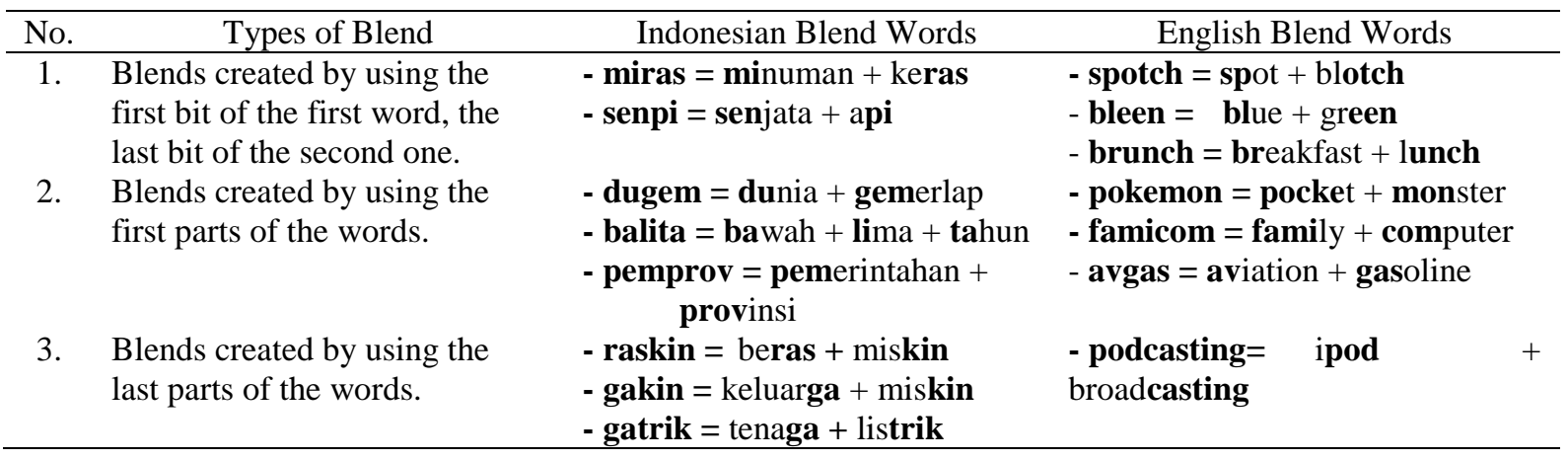




$$
\text { LingTera,6 (1), } 2019 \text { - } 3
$$

Mia Rahmannia, Pratomo Widodo

Table 2. The Differences between Indonesian Blend Words and English Blend Words

\begin{tabular}{|c|c|c|c|}
\hline No. & Types of Blend & Indonesian Blend Words & English Blend Words \\
\hline 1. & $\begin{array}{l}\text { Combining the beginning and the } \\
\text { middle part of the words. }\end{array}$ & $\begin{array}{l}\text { - disdik }=\text { dinas }+ \text { pendidikan } \\
\text { - naker }=\text { tenaga }+ \text { kerja }\end{array}$ & $\begin{array}{l}\text { Does not have this kind of } \\
\text { blend }\end{array}$ \\
\hline 2. & $\begin{array}{l}\text { Combining the middle and the end } \\
\text { part of the words. }\end{array}$ & $\begin{array}{l}- \text { curanmor }=\text { pencurian }+ \\
\text { kendaraan }+ \text { bermotor }\end{array}$ & $\begin{array}{l}\text { Does not have this kind of } \\
\text { blend }\end{array}$ \\
\hline 3. & $\begin{array}{l}\text { Blend words which taking the first } \\
\text { syllable from the first word and the } \\
\text { first letter from the next word. }\end{array}$ & $\begin{array}{l}\text { - perpamsi }=\text { persatuan }+ \\
\text { perusahaan }+ \text { air }+ \text { minum }+ \\
\text { seluruh }+ \text { Indonesia }\end{array}$ & $\begin{array}{l}\text { Does not have this kind of } \\
\text { blend }\end{array}$ \\
\hline 4. & $\begin{array}{l}\text { Blend words which taking the first } \\
\text { syllable from the first word and the } \\
\text { the second word and taking the first } \\
\text { letter from the next word. }\end{array}$ & $\begin{array}{l}\text { - formappi = forum + } \\
\text { masyarakat + peduli + parlemen } \\
\text { + Indonesia } \\
\text { - paraku = pasukan + rakyat + } \\
\text { Kalimantan + Utara } \\
\text { - markoak = markas + komando } \\
\text { + angkatan + kepolisian }\end{array}$ & $\begin{array}{c}\text { Does not have this kind of } \\
\text { blend }\end{array}$ \\
\hline 5. & $\begin{array}{l}\text { Overlapping blends occur when } \\
\text { the final part of the first word } \\
\text { overlaps the first part of the } \\
\text { second word. }\end{array}$ & Does not have this kind of blend & $\begin{array}{l}\text { - slanguage }=\text { slang }+ \\
\text { language } \\
\text { - celebrity }=\text { cell }+ \text { celebrity } \\
\text { - cartune }=\text { cartoon }+ \text { tune }\end{array}$ \\
\hline 6. & $\begin{array}{l}\text { Blends which keep the whole part } \\
\text { of the first word and the last part } \\
\text { of the second word. }\end{array}$ & Does not have this kind of blend & $\begin{array}{l}\text { - } \text { babelicious }=\text { babe }+ \\
\text { delicious } \\
\text { - foodoholic }=\text { food }+ \\
\text { alcoholic } \\
\text { - } \text { bookazine }= \\
\quad \text { book }+ \\
\text { magazine }\end{array}$ \\
\hline 7. & $\begin{array}{l}\text { Blends which keep part of the first } \\
\text { word plus whole of the second } \\
\text { word. }\end{array}$ & Does not have this kind of blend & $\begin{array}{l}\text { - Eurasia = Europe }+ \text { Asia } \\
\text { - fugly }=\text { fucking }+ \text { ugly } \\
\text { - automagic }=\text { automatic } \\
\text { + magic }\end{array}$ \\
\hline 8. & $\begin{array}{l}\text { Blending with clipping and } \\
\text { overlapping. It happens due to the } \\
\text { clipping of the word to share a } \\
\text { syllable before they are combined. }\end{array}$ & Does not have this kind of blend & $\begin{array}{l}\text { - pomato = po }(\mathrm{t}) \text { ato }+(\text { to }) \\
\text { mato } \\
\text { - federast }=\text { federa }(\text { list })+ \\
(\text { pe }) \text { derast } \\
\text { - glocal = glo }(\mathrm{bal})+\text { local }\end{array}$ \\
\hline
\end{tabular}

\section{Discussion}

\section{Indonesian Blend Word}

According to (Zaim, 2017), blending is a type of Indonesian word formation that is commonly found in mass media in Indonesia. Primarily blending is created by combining two or more parts of words to create a new word. Parts of the words which are connected may be in the beginning, middle, and the end of the words. Parts of the words which are combined have some variations; combining the beginning parts of each word, the beginning and end parts of words, the beginning and the middle parts of words, the middle and end parts of words, the end parts of each words, and the beginning, middle and the final parts of the words. Almost all combining systems can be obtained, except the combining system involving only the middle parts of the words (Zaim, 2017). (a) Combining the beginning part of the words, for examples;

$$
\begin{aligned}
& \text { dugem = dunia }+ \text { gemerlap } \\
& \text { balita }=\text { bawah }+ \text { lima }+ \text { tahun } \\
& \text { tipikor }=\text { tindak }+ \text { pidana }+ \text { korupsi } \\
& \text { pemprov = pemerintahan }+ \text { provinsi } \\
& \text { jamkesmas = jaminan }+ \text { kesehatan }+ \\
& \text { masyarakat }
\end{aligned}
$$

(b) Combing the beginning and the end part of the words, for examples;

$$
\begin{aligned}
& \text { Miras = minuman }+ \text { keras } \\
& \text { Senpi }=\text { senjata }+ \text { api } \\
& \text { Ponsel }=\text { telepon }+ \text { selular } \\
& \text { Gaptek = gagap }+ \text { teknologi }
\end{aligned}
$$

(c) Combining the beginning and the middle part of the words, for example;

Disdik $=$ dinas + pendidikan 


\section{LingTera,6 (1), 2019 - 4}

Mia Rahmannia, Pratomo Widodo

\section{Naker $=$ tenaga + kerja}

(d) Combining the middle and the end part of the words, for example;

curanmor $=$ pencurian + kendaraan + bermotor

(e) Combining the end and the end part of the words, for example:

$$
\begin{aligned}
& \text { raskin }=\text { beras }+ \text { miskin } \\
& \text { gakin }=\text { keluarga }+ \text { miskin } \\
& \text { gatrik = tenaga }+ \text { listrik }
\end{aligned}
$$

(f) Blend words which taking the first syllable from the first word and the first letter from the next word (Menur \& Ichwan, 2011), for example;

perpamsi $=$ persatuan + perusahaan + air + minum + seluruh + Indonesia

(g) Blend words which taking the first syllable from the first word and the the second word and taking the first letter from the next word (Permatasari, \& Suyudi, 2011), for example;

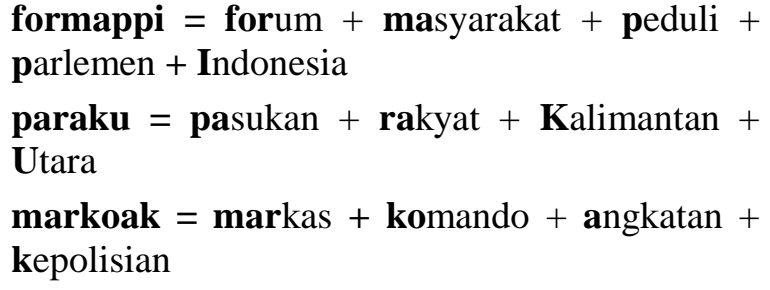

markoak $=$ markas + komando + angkatan + kepolisian

From the above examples, it shows that Indonesian blend words tend to be created by taking the word element anywhere, just form a new word that is memorable and easy to remember by the listener. Indonesian blend words can also be done without considering syllable or not syllable, but its little bit strange to the ear to listen to it and sounds unfamiliar.

Moreover, the result of the previous research by Permatasari \& Suyudi (2011) shows that every Indonesian blend words sample has a phonotactic pattern. In phonology, phonotactics is the study of the ways in which phonemes are allowed to combine in a particular language. Phonotactics is a branch of phonology that studies the permissible strings of phonemes in a language. The syllable is a central unit in phonotactic description, although sometimes the principles governing the distribution of phonemes go beyond the confines of a single syllable (Lass, 1984). A syllable is one or more letters representing a unit of spoken language consisting of a single uninterrupted sound. Adjective: syllabic. A syllable is made up of either a single vowel sound (as in the pronunciation of oh) or a combination of vowel and consonant(s) (as in no and not) (Nordquist, 2019).

\section{English Blend Word}

Blending is usually classified based on the process of its formation. (Enarsson, 2007, pp. 47; Giyatmi et al, 2017) classified blending as;

\section{Blending with Overlapping}

The most common overlapping blends occur when the final part of the first word overlaps the first part of the second word. The overlap can be one phoneme or several phoneme (Hosseinzadeh, 2014). In English context, such as;

slanguage $=$ slang + language $/$ language

characterized by excessive use of slang. celebrity $=\underline{\text { cell }}+\underline{\text { celebrity } / \text { famous criminal. }}$

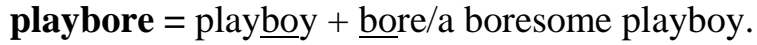
cartune $=$ cartoon + tune $/$ musical cartoon . anecdotage $=$ anecdote + dotage $/$ garrulous old age, anecdotes collectively.

\section{Blending with Clipping}

There is no overlapping in blending with clipping. Instead one part or more is omitted. There are different patterns that are used when creating these kinds of blends. They include subdivisions concerning the numbers and locations of the clippings: The second classification contrasts syntagmatic blends, so-called telescope blends of source words that usually co-occur sequentially like radarange (radar + range) and associative blends, blends of source words that were usually semantically linked in the word maker's mind. (Algeo, 1977; Benczes, 2019; Hosseinzadeh, 2014; Moehkardi, 2019).

There are different types of clipping. First, Blends created by using the first bit of the first word, the last bit of the second one:

spotch $=\underline{\text { spot }}+$ blotch $/$ make a blot or smear.

guck $=$ goo + muck $/$ a dirty or otherwise unpleasant substance.

chexting $=$ cheating + texting/cheating the texting.

bleen $=\underline{\text { blue }}+$ green/the mixture of two colors. geep $=$ goat + sheep $/$ A sheep-goat hybrid .

brunch $=$ breakfast + lunch $/$ having breakfast and lunch at the same time.

Second, Blends which keep the whole part of the first word and the last part of the second word: 
babelicious $=\underline{\text { babe }}+$ delicious/ (of a woman) sexually very attractive.

foodoholic $=\underline{\text { food }}+$ alcoholic/ often uncontrollable craving for food.

sunbrella $=\underline{\text { sun }}+$ umbrella $/$ An umbrella used to shade the sun.

blacktress $=$ black + actress $/$ An AfricanAmerican woman who is a pioneer of the film industry.

bookazine $=\underline{\text { book }}+$ magazine $/$ a publication combining elements of books and magazine.

Third, Blends which keep part of the first word plus whole of the second word

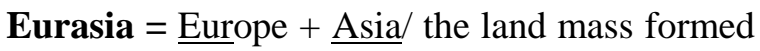
by the continents of Europe and Asia

Cheaster $=$ Christmas + Easter/ An individual who attends religious services only twice a year, at Christmas or Easter.

fugly $=$ fucking $+\underline{u g l y} /$ very ugly or unattractive. automagic $=$ automatic $+\underline{\text { magic }} /$ a process carried out automatically in such a clever way that the result appears to be magic.

$\operatorname{dup}=\underline{\mathrm{do}}+\underline{\mathrm{up}} /$ to open.

Fourth, Blends created by using the first parts of two words:

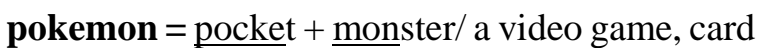
game, or other toy featuring certain Japanese cartoon characters.

famicom $=\underline{\text { family }}+$ computer/ The Nintendo Entertainment System is an 8-bit video game console that was developed and manufactured by Nintendo.

avgas $=$ aviation + gasoline $/$ gasoline fuel for aircraft.

Fifth, Blends created by using the last parts of two words:

podcasting $=$ ipod + broadcasting/ a program (as of music or talk) made available in digital format for automatic download over the internet.

\section{Blending with Clipping and Overlapping}

There are blends that can be created by both clipping and overlapping. It happens due to the clipping of the word to share a syllable before they are combined (Hosseinzadeh, 2014), such as;

californication $=$ californi $(a)+$ fornicat $(e) /$ It is an American comedy-drama television series created by Tom Kapinos.

pomato $=$ po (t) ato + (to) mato/ a hybrid or chimera produced by grafting a tomato plant and a potato plant. feminazi $=$ feminin (ist) + Nazi $/$ a radical feminist.

federast $=$ federa (list) + (pe) derast $/ \mathrm{A}$ federalist, especially in the EU.

glocal $=$ glo $($ bal $)+$ local $/$ being both global and local.

Moreover, in English blend words, the research that conducted by Hosseinzadeh (2014), the result shows that most of the blends are made by clipping: using the first part of the first word and the last part of the second word, and the second most common form is clipping and overlapping. Yule says blending similar to compounding also involves the combination of two separate forms to produce a single new term. However, blending is typically accomplished by taking the beginning of one word and joining it to the end of the other word (Yule, 2016, 53-59).

Furthermore, Kemmer (2006, pp.2-6) also gives some explanation dealing with the type of blending based on its characteristics, such as:

\section{Interactive Blends}

These blends occurs in which the two words involved in the blends are so tightly integrated in the blended word that the sounds of one source lexemes are interspersed between the sounds of the other (Kemmer, 2006, p. 3). The examples of intercalative blends are;

$$
\begin{gathered}
\text { Chuckle + Snort--.- Ch...le + Snort } \\
\text { chORTle } \\
\text { Slimy + Lithe - Sl. } y+\text { Lithe } \\
\text { SliTHy }
\end{gathered}
$$

\section{Substitution Blends}

Sometimes there is a substitution of a part of one source word or lexemes in the process of bending. These blends are called substitution blends such as car + hijacking (carjacking), stool + stargazing (stoolgazing).

\section{CONCLUSION}

Based on the results of data analysis and research findings stated above, the results of this research can be summarize as follows. In Indonesian blend words, the shift of blending occurred with the development of variants of the blended words (combining beginning, end, or middle of the word or just the first letter of the word itself) and Indonesian blend words does not 


\section{LingTera,6 (1), 2019 - 6}

Mia Rahmannia, Pratomo Widodo

have overlapping blending like the one owned by English blend language. Besides, there are several types of English words that form blended formation which keep the whole part of the first word and the last part of the second word and conversely. Therefore, Indonesian blend words and English blend words not only have similarities but also have their differences that make them unique to each other.

The results of this study have implications to the reader to gets more information about both Indonesian and English blend words based on its types, the similarities and the difference between them. The writer suggest for further researcher to discuss about whether the Indonesian blend words influence to the slang language in Bahasa Indonesia.

\section{REFERENCES}

Algeo, J. (1977). Blends, a structural and systemic view. American speech, 52(1/2), 47-64.

Bauer, L., \& Laurie, B. (1983). English wordformation. Cambridge university press.

Bednárová-Gibová, K. (2014). Some insights into portmanteau words in current fashion magazines. Jazyk a Kultúra, 5(19-20), 0-0.

Benczes, R. (2019). Rhyme over reason: phonological motivation in English. Cambridge University Press.

Berelson, B. (1952). Content analysis in communication research. New York, NY, US: Free Press.

Creswell, J. W. (1994). Research design qualitative and quantitative approach. California: Sage Publications, Inc.

Enarsson, A. (2007). New blends in the English language. Karlstad University. Retrived from

http://urn.kb.se/resolve?urn=urn:nbn:se:ka u:diva-674

Giyatmi, G., Wijayava, R., \& Arumi, S. (2017). Blending words found in social media. JURNAL ARBITRER, 4(2), 65-75. Retrived from http://arbitrer.fib.unand.ac.id/index.php/ar bitrer/article/view/81

Graneheim, U. H., \& Lundman, B. (2004). Qualitative content analysis in nursing research: concepts, procedures and measures to achieve trustworthiness. Nurse education today, 24(2), 105-112.

Gries, S. T. (2004). Shouldn't it be breakfunch? A quantitative analysis of blend structure in English. Linguistics, 42(3), 639667.doi:http://dx.doi.org/10.1515/ling.200 4.021

Hamelink, C. J. (2004). Toward a human right to communicate?. Canadian Journal of Communication, 29(2). Retrived from https://www.cjconline.ca/index.php/journal/article/view/1 $436 / 1548$

Hosseinzadeh, N. M. (2014). New blends in English language. International Journal of English Language and Linguistics Research, 2(2), 15-26.

Kemmer, S. (2006). Schemas and lexical blends, Universitat Duisburg-Essen.

Lass, R. (1984). Phonology: An introduction to basic concepts. Cambridge University Press.

Moehkardi, R. (2019). English blends in Indonesian context: Their formation processes and meanings. Jurnal Humaniora, 31(1), 21-32. /*doi:http://dx.doi.org/10.22146/jh.v31i1. 40374*/ doi:https://doi.org/10.22146/jh.v31i1.403 74

Nordquist, R. (2019). What Is a Syllable in the English Language? ThoughtCo. https://www.thoughtco.com/syllabledefinition-1692165

Peresich, C. (2015). Blends. A creative means of word-formation. GRIN Verlag.

Permatasari, M., \& Suyudi, I. (2011). The patterns of Indonesian blend words. In Proceeding of Uzbek-Indonesian Joint International Conference, 1. Gunadarma University.

Rizkiyanto, A. (2014). Comparison between using authentic song lyrics and pictures as media to teach students'writing competence of narrative text. ELT Forum: Journal of English Language Teaching, 3 (1), 1-9. Retrived from https://journal.unnes.ac.id/sju/index.php/e lt/article/view/4001 


\section{LingTera, 6 (1), 2019 - 7}

Mia Rahmannia, Pratomo Widodo

Yule, G. (2016). The study of language. New York: Cambridge University Press, pp. 539.

Zaim, M. (2017). Shifting the system of Indonesian word formation; the study on morphology and sociolinguistics of acronyms, blending, and clipping.
Humanus, 16(2), 248-262. doi: https://doi.org/10.24036/humanus.v16i2.8 690

Zimmer, B. (2010). Acronym. The New York Times Magazine. Retrieved from https://www.nytimes.com/2010/12/19/ma gazine/19FOB-onlanguage-t.html 